\title{
Lung Function Tests in Children with and without Sickle Cell Anaemia at South Western Nigerian Tertiary Hospitals
}

\author{
Onigbinde Michael Olaniyan $^{1}$, Oninla Samuel Olorunyomi ${ }^{1}$ \\ ${ }^{1}$ Department of Paediatrics and Child Health, Ladoke Akintola University of Technology, Ogbomosho, \\ Oyo State, Nigeria. \\ Corresponding Author: Oninla Samuel Olorunyomi
}

\begin{abstract}
Sickle cell anaemia (SCA) is a common cause of morbidity and mortality in Nigerian children. Sickle cell haemoglobin disorder and carrier state have incidence at birth in Nigeria of about $2 \%$ and 25\% respectively. The Chronic anaemia and recurrent vaso-occlusion in this disease condition can lead to impairment of function of body organs or systems. The knowledge on how SCA affects the lung and pulmonary tissue function in Nigerian children is inadequate.

Aims: To compare lung function tests results of apparently healthy sickle cell anaemia patients recruited from tertiary hospitals in South West Nigeria with those of apparently healthy controls.

Method: A comparative cross sectional study of children attending the Sickle Cell anaemia clinics of Wesley Guild Hospital, Obafemi Awolowo University Teaching Hospital Complex and Ladoke Akintola University of Technology Teaching Hospital was done. Ethical approval was obtained from the Ethical review boards of the different hospitals where the studies were conducted. Randomly selected consenting matched apparently well children and children with Sickle cell anaemia had their weights, height and Packed cell volume on the days of their clinics. In addition the Forced Expiratory Volume at one second, Forced Vital capacity and Peak expiratory flow rates were measured and recorded. The data obtained was analyzed using SPSS 12 version.

Results: The total of 74 HBSS patients studied comprised of 35(43.7\%) boys and 39 (52.7\%) girls, giving a male to female ratio of 1: 1.1, while the 73 apparently healthy controls were made up of $39(53.4 \%)$ boys and $34(46.6 \%)$ girls, giving a male to female ratio of $1.2: 1.0$. The mean weight and BMI of the children with SCA were $24.9 \pm 8.0 \mathrm{~kg}$ and $14.4 \pm 1.8 \mathrm{~m}^{2}$ compared with $29.4 \pm 2.9 \mathrm{~kg}$ and $15.4 \pm 1.8 \mathrm{~m}^{2}$ in the apparently healthy controls. Higher values of weight and BMI in healthy controls than in the SCA subjects and statistically significant $\mathrm{p}<0.05$. The mean values of the FEV ${ }_{1}, \mathrm{FVC}$, PEFR and FEV percent were $1.54 \pm 0.51,1.76 \pm 0.45,271.37 \pm 72.20$ and $87.5 \pm 4.43$ respectively in children with SCA as against $1.83 \pm 0.61,2.03 \pm 0.65,296.44 \pm 75.0$ and $90.2 \pm 5.76$ respectively in the healthy controls. Higher lung function tests are statistically significant $(\mathrm{p}<0.05)$

Conclusion: Children with Sickle Cell anaemia have significantly lower anthropometric measurement and lung function test values (FEV1, FVC, \& PEFR) than controls. The lower lung function test values in the sickle cell anaemia patients may be as a result of the lower anthropometric measurements. Further studies need to be conducted find out why the lung function tests are lower in children with sickle cell anaemia preferably after eliminating cofounders such as anthropometry.
\end{abstract}

Keywords: Lung Function Tests, Sickle Cell Anaemia, Children

\section{INTRODUCTION}

Sickle cell anaemia (SCA) is the most common inherited genetic disorder in sub-Saharan Africa. It is associated with lifelong morbidity and mortality. ${ }^{1}$ The disorder manifests in sickling of red blood cells under hypoxic and other stress conditions, resulting in shorten red blood 
cell life span, recurrent sickling, vasoocclussion and chronic anaemic condition. 2,3 All organs are affected by this chronic anaemic condition which eventually impacts negatively on tissue, organ or system development over the years of growth. The recurrent sickling experienced by individuals with sickle cell anaemia may lead to recurrent tissue or organ damage and this may eventually lead to organ destruction and failure

Lung disease has been reported to be the most common reason for hospital admission among children with sickle cell anemia. ${ }^{3}$ Acute chest syndrome and pulmonary hypertension are the most notable chest complications among children with SCA. ${ }^{3}$ These complications which may be due to the recurrent sickling resulting in lung destruction or infarcts and the chronic anemia experienced over the years are likely to impact negatively on lung function.

Diseases of the lungs have also been reported to be the most common cause of mortality among individuals with SCA and the most common reason for hospital admission. ${ }^{4,5}$ However, studies on lung function in Nigerian children with sickle cell anaemia are scarce and suggest that a restrictive respiratory pattern of lung function on spirometric testing are not uncommon. ${ }^{4}$ The large gap in knowledge on pulmonary function in children with sickle cell anemia was the drive to carry out this study. The present study aims to assess pulmonary function tests such as Forced expiratory volume in 1 second (FEV1), Forced vital capacity (FVC) and Peak expiratory flow rates (PEFR) in children with sickle cell anaemia across different age groups. Furthermore, the study aims to compare the findings in the children with SCA with matched healthy controls.

\section{METHODOLOGY}

The study was a prospective case control study carried out in the Paediatric Hematology out-patient clinics of all the tertiary teaching hospitals in Osun state, namely; Obafemi Awolowo University Teaching Hospital Complex, Ile-Ife, Wesley Guild Hospital, Ilesa and Ladoke Akintola University of Technology Teaching Hospital, Osogbo. Institutional ethical approval was obtained from all the institutions of study. Informed Consent was also obtained from the patients and their care givers.

All consecutive consenting steady state children with SCA attending the Paediatrics Haematology out-patient clinics at the different teaching hospitals were coopted. Appropriately matched healthy controls for age and sex were randomly selected at the well out-patient clinics. Pertinent information such as age and sex were obtained.

Other details obtained after appropriate examinations were the weights and heights. The pulmonary function was assessed using a single-breath wedge bellow Vitalograph and a Wright peak flow meter. The subjects and controls were given sessions of teachings and practice till the techniques of performing the test were mastered. Each subject was allowed three blows and the values of Forced expiratory volume in 1 second and Forced vital capacity were recorded on the spirogram while the peak expiratory flow rates were recorded on the Wrights peak flow meter. The highest of the three best readings were taken. The standard Vitalograph chart used in this study was self-correcting for body temperature at normal barometric pressure with water vapour.

The data was analysed using Statistical package for Social Sciences version 12. The means, standard deviations for the weights, body mass index, forced expiratory volume in one second, forced vital capacity and peak expiratory flow rates were generated. Chi square test and analysis of variance (ANOVA) were applied to compare the subjects and controls. $\mathrm{P}$ values less than 0.05 were taken to be statistically significant. 


\section{RESULTS}

\section{General results}

A total of 74 HBSS subjects met the inclusion criteria and were studied. Forty one (41) subjects were from Ife State Hospital and 22 from Wesley Guild Hospital Ilesa, both units are of Obafemi Awolowo University Teaching Hospital Complex (OAUTHC), Ile Ife and 11 subjects were from Ladoke Akintola University of Technology (LAUTECH) Teaching Hospital, Osogbo. Seventy three (73) randomly selected apparently healthy children matched for age and sex were recruited into the study as controls. Forty two (42) controls were from Ife State Hospital, 21 from Wesley Guild Hospital Ilesa and ten from LAUTEH teaching Hospital.

\section{Age and Sex distribution}

Of the 74 HBSS patients $35(47.3 \%)$ were boys and 39(57.2\%) were girls giving a male to female ratio of 1.0: 1.1 , while out of the 73 , controls $39(53,4 \%)$ were boys and $34(46.6 \%)$ were girls giving a male to female ratio of 1.2: 1.0. The ages of the HBSS subjects and controls ranged from 5 to 15 years with a mean of $10.6 \pm 3.3$ years and $10.3 \pm 3.5$ years respectively

\section{Anthropometric data of studied subjects}

The mean weights of the subjects with HBSS and the controls were $25.1 \pm$
$7.9 \mathrm{~kg}$ and $29.4 \pm 11.9 \mathrm{~kg}$ respectively. The differences in the weights are statistically significant $\mathrm{P}=0.02$. The mean heights in the subjects with HBSS and the controls were $131.2 \mathrm{~cm} \pm 19.1$ and $135.7 \pm 18.2 \mathrm{~cm}$ respectively. The differences in the heights are not significant $\mathrm{P}=0.07$. Concerning the mean Body mass index (BMI), the mean in the subjects with HBSS and controls were $14.4 \pm 1.8 \mathrm{~kg} / \mathrm{m}^{2}$ and $15.4 \pm 2.9 \mathrm{~kg} / \mathrm{m}^{2}$ respectively. The differences in BMI are statistically significant $\mathrm{P}<0.01$.

\section{Lung function tests of the studied subjects across difference age groups}

The spirometric lung function tests values for $\mathrm{FEV}_{1}, \mathrm{FVC}$ and PEFR were higher in the apparently healthy controls. These differences were statistically significant; the details of the lung function test and the comparison are shown in Table 1. It will be seen that the pulmonary function test obtained values are generally higher in the controls than the subjects.

Lung function tests of the studied subjects across different age groups

A progressive increase in the spirometric lung values for $\mathrm{FEV}_{1}, \mathrm{FVC}$ and PEFR were obtained across different age groups. The differences between the values obtained for the pulmonary function tests for the subjects and controls were statistically significant across the age groups. Full details are given in Table 2

Table 1: Comparison of the mean pulmonary function test amongst subjects and controls

\begin{tabular}{|l|l|l|l|}
\hline Pulmonary function test & Subjects Mean(SD) & Controls Mean(SD) & P value \\
\hline PEFR (L/min) & $271.37(72.198)$ & $296.44(74.97)$ & 0.041 \\
\hline FEV1 & $1.54(0.513)$ & $1.83(0.61)$ & 0.002 \\
\hline FVC & $1.76(0.499)$ & $2.03(0.65)$ & 0.000 \\
\hline
\end{tabular}

$P E F R=$ Peaked expiratory flow rate, FEVI = Forced expiratory volume in one second, FVC $=$ Forced vital capacity

Table 2: Comparison between pulmonary function test per age groups in HBSS subjects and control

\begin{tabular}{|c|c|c|c|c|c|c|}
\hline \multirow{2}{*}{$\begin{array}{l}\text { Pulmonary } \\
\text { function test }\end{array}$} & & \multicolumn{5}{|c|}{ Age group (years) Category } \\
\hline & & $\begin{array}{l}5.0-<8.0 \text { Mean } \\
\text { (SD) }\end{array}$ & $\begin{array}{l}>8.0-10.0 \text { Mean } \\
\text { (SD) }\end{array}$ & $\begin{array}{l}>10.0-<14.0 \text { Mean } \\
\text { (SD) }\end{array}$ & $\begin{array}{l}\begin{array}{l}\text { Above } 14 \\
\text { (SD) }\end{array} \\
\text { Mean }\end{array}$ & $\begin{array}{l}\mathbf{P} \\
\text { value }\end{array}$ \\
\hline $\begin{array}{l}\text { PEFR } \\
(\mathrm{L} / \mathrm{min})\end{array}$ & $\begin{array}{l}\text { Subject } \\
\text { Control } \\
\text { P value }\end{array}$ & $\begin{array}{l}181.75(30.62) \\
203.60(29.70) \\
0.022\end{array}$ & $\begin{array}{l}247.08(37.81) \\
286.00(22.95) \\
0.000\end{array}$ & $\begin{array}{l}307.73(46.08) \\
343.68(33.37) \\
0.008\end{array}$ & $\begin{array}{l}328.00(55.81) \\
360.24(41.06) \\
0.041\end{array}$ & $\begin{array}{l}<0.001 \\
<0.001\end{array}$ \\
\hline $\begin{array}{l}\text { FEV1 } \\
\text { (L) }\end{array}$ & $\begin{array}{l}\text { Subject } \\
\text { Control } \\
\text { P value }\end{array}$ & $\begin{array}{l}1.15(0.35) \\
1.16(0.21) \\
0.91\end{array}$ & $\begin{array}{l}1.29(0.41) \\
1.56(0.22) \\
0.058\end{array}$ & $\begin{array}{l}1.58(0.39) \\
2.04(0.27) \\
0.000\end{array}$ & $\begin{array}{l}2.01(0.45) \\
2.51(0.35) \\
0.000\end{array}$ & $\begin{array}{l}<0.001 \\
<0.001\end{array}$ \\
\hline $\begin{array}{l}\text { FVC } \\
\text { (L) }\end{array}$ & $\begin{array}{l}\text { Subject } \\
\text { Control } \\
\text { P value }\end{array}$ & $\begin{array}{l}1.36(0.35) \\
1.32(0.22) \\
0.652\end{array}$ & $\begin{array}{l}1.48(0.41) \\
1.71(0.23) \\
0.131\end{array}$ & $\begin{array}{l}1.81(0.28) \\
2.28(0.27) \\
0.000\end{array}$ & $\begin{array}{l}2.24((0.45) \\
2.73(0.38) \\
0.001\end{array}$ & $\begin{array}{l}<0.001 \\
<0.001\end{array}$ \\
\hline
\end{tabular}

PEFR $=$ Peaked expiratory flow rate, FEVI = Forced expiratory volume in one second, FVC = Forced vital capacity 


\section{DISCUSSION}

The present study has documented the lung function tests in children with sickle cell anemia as compared with that of apparently healthy age and sex matched controls. The values of lung function tests results were found to be significantly lower in the HBSS subjects compared with that of the controls. This is not an unexpected result considering that chest diseases such as infections, acute chest syndrome and pulmonary hypertension are prevalent disease conditions among individuals with SCA ${ }^{4,6,7}$ Infections and infarctions can be recurrent and this can damage the lung and bring about limitation in its function, The findings of reduced spirometric readings in children with SCA are similar to those of Isqro et al who reported reduced spirometric levels in close to half of the population studied with Bone marrow transplant. ${ }^{4}$ However, our results partly contrast the study by Willen et al which reported more than half of the children with sickle cell anaemia studied having a normal lung function tests.However. ${ }^{6}$

A low mean weight and BMI of children with Sickle cell anaemia in comparison to apparently healthy children was recorded in the present study. This finding is consistent with results from other studies. ${ }^{7,8,9}$. A low mean weight and BMI in children with SCA may be due to the lifelong chronic anaemia and recurrent sickling experienced. The explanation for this study may that a relatively low BMI in the SCA cohorts will be associated with a small body and conversely small lungs. Thus, this correlation introduces a cofounder to SCA that cannot entirely account for the significantly low lung function tests values among subjects with SCA cohort groups in contrast to the healthy controls.

A progressive increase in the lung function tests/parameters values across the age category distributions was recorded in the present study. This positive finding sharply contrasts the report by Willen et al, where age was found to be a predictor of a decrease in lung function. The present finding of $\mathrm{s}$ progressive increase in lung function parameter values with increasing age categories may be explained by the progressive growth of the respiratory system, thus improving its lung volume. On the other hand, a decrease in lung volume with aging is also a logical expectation and can also be explained by a progressive insult of chronic anaemia and intermittent infarction to the lungs which can have a cumulative damaging effect with aging.

It is concluded from the present study that children with sickle cell anaemia have lower pulmonary lung functions such as Forced expiratory volume in 1 second, forced vital capacity and peak expiratory flow rates and relatively lower anthropometry reading compared to their healthy peers. A progressive increase in FEV1, FVC and PEFR is expected in children with SCA as they grow up. Further researches are thus recommended to study the association between SCA and lung function tests with cofounders such as anthropometry excluded.

\section{ACKNOWLEDGEMENT}

Professor Gabriel Ademola Oyedeji, a retired Consultant and Professor of Social Paediatrics is highly appreciated for review of the manuscript of this article.

\section{Conflict of Interest: None}

\section{Source of Funding: None}

\section{Ethical Approval: Approved}

\section{REFERENCES}

1. Obaro SK, Daniel Y, Lawson JO, Hsu WW, Dada J, Essen U, Ibrahim K, Akindele A, Brooks K, Olanipekun G, Ajose T, Stewart CE, Inusa BP. Sickle-Cell Disease in Nigerian Children: Parental Knowledge and Laboratory Results. Public Health Genomics. 2016;19(2):102-7. doi: 10.1159/000444475. Epub 2016 Mar 19. PMID: 26991896.

2. Allali S, Taylor M, Brice J, Montalembert M. Chronic organ injuries in children with 
sickle cell disease. Haematologica. 2021; 106(6):1535-1544. Published 2021 Jun 1. doi:10.3324/haematol.2020.271353

3. Kim Smith-Whitley. Sickle cell anemia in Nelsons Textbook of paediatrics $21^{\text {st }}$ edition. Pg 2541 - 2550. Editors Kleigman RM, Blum NJ, Shah SS, ST Geme JW, Tasker RC, Wilson KM, Behrman RE (editors). Publisher Elsevier, Philadephia

4. Isgro' $\mathrm{A}$, Marziali $\mathrm{M}$, Paciaroni $\mathrm{K}$, et al. Spirometric Evaluation of Pulmonary Function in Nigerian Children underwent Bone Marrow Transplantation for Sickle Cell Anemia. Mediterr J Hematol Infect Dis. 2017;9(1):e2017030. Published 2017 Apr 15. doi:10.4084/MJHID.2017.030

5. Kaya Z, Weiner DJ, Yilmaz D, Rowan J, Goyal RK. Lung function, pulmonary complications, and mortality after allogeneic blood and marrow transplantation in children. Biol Blood Marrow Transplant. 2009 Jul;15(7):817-26. doi: 10.1016/j.bbmt.2009.03.019. Erratum in: Biol Blood Marrow Transplant. 2009 Sep;15(9):1141. PMID: 19539213

6. Willen SM, Cohen R, Rodeghier M, Kirkham F, Redline SS, Rosen C, Kirkby J, DeBaun MR. Age is a predictor of a small decrease in lung function in children with sickle cell anemia. Am J Hematol. 2018 Mar;93(3):408-415. doi: 10.1002/ajh.25003. Epub 2018 Jan 25. PMID: 29226507; PMCID: PMC5803370.

7. Cox SE, Makani J, Fulford AJ, Komba AN, Soka D, Williams TN, Newton CR, Marsh K, Prentice AM. Nutritional status, hospitalization and mortality among patients with sickle cell anemia in Tanzania. Haematologica. 2011 Jul;96(7):948-53. doi: 10.3324/haematol.2010.028167. Epub 2011 Apr 1. PMID: 21459787; PMCID: PMC3128212.

8. Jesus, Amanda Cristina da Silva de et al. "socioeconomic and nutritional characteristics of children and adolescents with sickle cell anemia: a systematic review." "característicassocioeconômicas e nutricionais de crianças e adolescentes com anemia falciforme: umarevisãosistemática." Revistapaulista de pediatria :orgaooficial da Sociedade de Pediatria de Sao Paulo vol. 36,4 (2018): 491-499. doi:10.1590/19840462/;2018;36;4;00010

9. Al-Saqladi AW, Cipolotti R, Fijnvandraat $\mathrm{K}$, Brabin BJ. Growth and nutritional status of children with homozygous sickle cell disease. Ann Trop Paediatr. 2008 Sep;28(3): 165-89. doi: 10.1179/146532808X335624. PMID: 18727846

10. Willen SM, Cohen R, Rodeghier M, et al. Age is a predictor of a small decrease in lung function in children with sickle cell anemia. Am J Hematol. 2018;93(3):408415. doi:10.1002/ajh.250

How to cite this article: Olaniyan OM, Olorunyomi OS. Lung function tests in children with and without sickle cell anaemia at South Western Nigerian Tertiary hospitals. Int $J$ Health Sci Res. 2021; 11(10): 348-352. DOI: https://doi.org/10.52403/ijhsr.20211045 